\title{
Cattle twins after transfer of demi-embryos derived from zona-perforated blastocysts
}

\author{
Maria Skrzyszowska, Z. Smorąg, Lucyna Kątska and M. Bochenek
}

\author{
Department of Animal Reproduction, \\ National Research Institute of Animal Production \\ 32-083 Balice, Poland
}

(Received 10 September 1998; accepted 19 March 1999)

\section{ABSTRACT}

This experiment investigated a method of bovine embryo bisection during hatching stimulated by a zona pellucida perforation. The method of bisection was intended to significantly lower cell loss which occurs during standard bisection. Blastocysts, obtained either in vitro or in vivo, had their zona pellucida perforated by puncturing or slitting near the inner cell mass and subsequently were cultured in vitro. During culture, hatching was characterized by the extrusion of the inner cell mass as well as trophoectodermal cells through the opening in the zona pellucida. At a certain point the hatching the blastocyst took on a figure eight shape. Cutting the narrow bridge of cells which connected both parts of the embryo led to a splitting of the embryo into two equivalent parts.

The experiment determined the factors responsible for effective hatching stimulated by earlier zona pellucida perforation. The optimal stage of bovine cmbryo development for obtaining the highest proportion of eight-in-shape hatching was late blastocyst. At this stage eight-in-shape hatching occurred in $50.4 \%$ of the cmbryos $(137 / 272)$ while in the case of middle blastocyst $28.3 \%(17 / 60)$ and expanding blastocysts $15.3 \%(11 / 72)$. In the cases of puncturing and slitting the zona pellucida there was a similar proportion of eight-in-shape hatching, 137/272 (50.4\%) and 93/190 (48.9\%), respectively.

Demi-embryos produced from thirty-five blastocysts bisected by the eight-in-shape method (modified bisection) were transferred into 41 recipients. Seventeen recipients became pregnant. All 17 calved, resulting in 20 calves, including 4 sets of monozygotic twins.

In the control group there were 13 recipients which received halves obtained from conventional blastocyst bisection. Two recipients became pregnant, resulting in 3 calves, including 1 set of monozygotic twins.

It can be concluded that the developed procedure of splitting embryos during stimulated hatching may be an alternative to standard embryo bisection.

KEY WORDS: cattle, blastocyst, hatching, zona-perforation, embryo splitting 


\section{INTRODUCTION}

The standard method of obtaining identical bovine embryos is the transfer of embryos that have been split either during the morula or blastocyst stages (Ozil, 1983; Baker, 1985; Mc Evoy and Sreean, 1990; Bredbacka et al., 1992). The practicality of these methods is still limited due to the lowered implantation rate of "halves" even though the highest quality embryos are used for bisection. Demi-embryos obtainined as a result of bisection contain half the number of cells in comparison to a whole embryo. Furthermore cell loss occurs during bisection. This loss is estimated as 13-16\% (Skrzyszowska and Smorag, 1989). This fact can be one reason for the lower implantation rate.

The procedure that we propose drastically reduces cell loss during splitting. Previously we observed that embryos with perforated zona pellucida, cultured in vitro, to a certain stage hatched in a specific way. Namely there was an expansion of the embryo through the hole in the zona pellucida. At a certain point during this process, the hatching embryo looks like the number eight. If the embryo at this phase of hatching is split, two separate embryo parts are obtained.

This experiment investigated the conditions of this specific way of hatching that make it possible to divide the embryo into two genetically identical parts and assessed the developmental potential in vivo of the resulting demi-embryos.

\section{MATERIAL AND METHODS}

This study was carried out on bovine embryos produced using IVM/IVF technology (Kątska and Ryńska, 1993; Skrzyszowska et al., 1997) or in vivo from superovulated donor heifers.

\section{In vitro}

Briefly, ovaries of slaughtered cattle (heifers and cows) were collected at the local abattoir and were transported to the laboratory. Vesicular follicles were isolated and ruptured while immersed in a manipulation medium (TMC 199 Earle's salt with HEPES', containing $10 \% \mathrm{FCS}^{2}$ ) and cumulus oocyte complexes (COCs) were freed and transferred to a maturation medium. Oocytes were matured in co-culture with granulosa cells in TCM 199 supplemented with $20 \%$ oestrous cow serum $\left(\mathrm{ECS}^{3}\right)$ for 23 to $24 \mathrm{~h}$ at $39^{\circ} \mathrm{C}$ under $5 \% \mathrm{CO}_{2}$ in air at maxi-

\footnotetext{
' Sigma Chemical Co., St. Louis, MO, USA

2 Sigma Chemical Co., St. Louis, MO, USA

3 serum prepared in our laboratory
} 
mum humidity. Next, matured oocytes were inseminated with heparin-treated ( 20 $\mathrm{IU} / \mathrm{ml}$ ) frozen-thawed bull spermatozoa. After 20 to $22 \mathrm{~h}$ zygotes were placed in co-culture with the bovine oviduct epithelial cell monolayer in Menezo B2 medi$\mathrm{um}^{4}$ (Khalifa et al., 1993) for 6 to 8 days to develop up to the blastocyst stage. Embryos at middle, late or expanded blastocyst stages were used. Individual blastocyst stage was determined on the basis of blastocoel size and the visibility of the inner cell mass.

In vivo

Embryos were obtained from donor heifers stimulated hormonally for superovulation according to standard methods of using gonadotropins ( $\mathrm{PMSG}^{5}$ or $\mathrm{FSH}^{6}$ ) during the luteal phase of the oestrous cycle. Embryos were flushed non-surgically 7 to 7.5 days after oestrus.

\section{Preparation of micro-instruments for zona pellucida perforation}

Perforation of the zona pellucida requires preparation of glass instruments such as: holding pipettes to hold the embryos and micropipettes or glass needles to puncture or to slit the zona pellucida.

Holding pipettes were glass capillaries $10-15 \mathrm{~cm}$ long with an outside diameter of $1 \mathrm{~mm}\left(\mathrm{Clark}^{7}\right)$. The capillaries were pulled in a gas or alcohol flame to a diameter of 120-150 $\mu \mathrm{m}$. For further adaptation of the pipette, a microforge (De Fonbrune $^{8}$ ) was used. The edges were cut evenly and melted. At the same time the inside diameter was narrowed to $40-50 \mu \mathrm{m}$. The next step was to form a special curvature (at an angle of $90^{\circ}$ ) which made it possible to mount the pipette in the manipulation chamber. Micropipettes for puncturing and glass needles for cutting were made in the same way with glass capillaries with a diameter of $1 \mathrm{~mm}$. The end of the capilliary was pulled with a programmed puller (Campden $\left.{ }^{9}\right)$. Needles therefore had a diameter of $1-2 \mu \mathrm{m}$, and micropipettes - approximately $30 \mu \mathrm{m}$. The next step was to polish the end of the micropipettes at a $45^{\circ}$ angle in order to get a diaganonal surface making it easier to penetrate the zona pellucida and then the polished edges were slightly melted.

\footnotetext{
${ }^{4}$ INRA, bio Merieux sa, Marcy, Etoile, France ${ }^{s}$ Serogonadotropin, Biowet, Drwalew, Poland

"Follicotropin, SPOFA, Praha, Czech Republic

${ }^{7}$ Clark Electromedical Instruments, Pangbourne, England

${ }^{8}$ CIT Alcatel, Annecy, France

${ }^{9}$ Campden InstrumentsLtd., Sileby, England
} 


\section{Perforating the zona pellucida}

Bovine blastocysts were placed in a glass manipulation chamber in prewarmed phosphate buffered saline $\left(\mathrm{PBS}^{10}\right.$ ) supplemented with $20 \% \mathrm{FCS}^{\prime \prime}$. Microinstruments were used: from one side a holding pipette and from the opposite side a micropipette or microneedle for perforation. This was done under an inverted Olympus IMT-2 $2^{12}$ microscope (magnification $\times 200$ ) and using a Leit ${ }^{13}$ micromanipulator.

With the holding pipette the embryo was orientated at a specified position (Skrzyszowska et al., 1997). Using a clock's face for comparison the optimal position was when the embryo inner cell mass was at 2-3 o'clock. Perforation was done by puncturing or slitting of the zona pellucida at 12 o'clock. Cutting was done by inserting the glass microneedle under the zona pellucida and puncturing the zona pellucida on the opposite side by moving the needle further along the zona pellucida without touching the embryo structure. At this moment the embryo "hung" on the glass needle. This fragment of the zona pellucida was more or less $1 / 10$ th of the embryo's circumference. After releasing the embryo from the holding pipette, yet still hanging from the needle, the embryo was placed directly under the holding pipette. By scraping the needle along the holding pipette the external surface of the zona pellucida was broken along the area where the needle was inserted. This procedure of the partial zona disection was based, in part, on the method used by Malter and Cohen (1989) and Khalifa et al. (1993).

Puncturing of the zona pellucida was done by inserting a micropipette with a diameter of approximately $30 \mu \mathrm{m}$ also at " 12 o'clock". The micropipette went through one wall of the zona pellucida till it came to the surface of the embryo, and then was removed.

\section{In vitro culture of the zona perforated blastocyst}

After perforating the zona pellucida, the embryos were cultured in Menezo B2 medium in a co-culture with epithelial cells (the embryos produced by using IVM/IVF/IVC technology; laboratory conditions) or in Menezo B2 medium supplemented with FCS (nonsurgically recovered embryos from superovulated heifers; farm conditions). Embryos were incubated at $38^{\circ} \mathrm{C}$ with $5 \% \mathrm{CO}_{2}$ in air and depending on the blastocyst stage (middle, late and expanding), for 48,24 or $8 \mathrm{~h}$, respectively. During this time hatching was checked every few hours. At a certain stage in the hatching there was a division of embryos into two parts, those already outside the zona pellucida and those still inside it. The two parts were connected

\footnotetext{
10 Sigma Chemical Co., St. Louis, MO, USA

" Sigma Chemical Co., St. Louis, MO, USA

12 Olympus Optical Co., Tokyo, Japan

${ }^{1.3}$ Leitz, Wetzlar, Germany
} 
only by a narrow bridge of cells and created a figure eight-in-shape. The bridge of cells was cut with a glass microneedle resulting in two equivalent embryo parts, in other words identical "halves". The halves, as previously described, obtained from blastocysts produced in vitro were cultured in Menezo B2 medium supplemented with foetal calf serum for observation of their reexpansion ability until the half became spherical, since they had shrunk slightly as a result of splitting.

The halves, produced in vivo, were transferred non-surgically to the reproductive tracts of synchronized recipients.

\section{Cell number evaluation of demi blastocysts}

In a certain number of the demi blastocysts produced by in vitro fertilization the number of cells was determined. To do this embryos were incubated in phosphate buffered saline (PBS) containing $5 \mu \mathrm{g} / \mathrm{ml}$ Hoechst $33342^{14}$ at room temperature for $15 \mathrm{~min}$. The embryos were then rinsed and placed in a drop under a cover slide. The number of cells was assessed by fluorescence microscopy counting the number of nuclei in each demi-embryo.

Statistical analysis differences between treatments were determined by a Chisquare test. The number of blastocysts hatching according to the desired figure eight pattern were compared between three stages of development. In addition a comparison was made of the two perforating techniques.

\section{RESULTS}

The eight-in-shape way of hatching was noted in $17 / 60(28.3 \%), 137 / 272(50.4 \%)$ and $11 / 72(15.3 \%)$ middle, late and expanding blastocysts, respectively (Table 1$)$. After splitting hatching embryos a majority of half pairs cultured in vitro showed

TABLE 1

The influence of the stage of development of perforated embryos on the eight-in-shape way of blastocyst hatching

\begin{tabular}{lcc}
\hline Stage of embryo & $\begin{array}{c}\text { Embryos } \\
\mathrm{n}\end{array}$ & $\begin{array}{c}\text { Hatching of blastocysts according to figure } \\
\text { cight pattern, \% }\end{array}$ \\
\hline Mid-blastocyst & 60 & $17(28.3)^{\mathrm{a}}$ \\
Late blastocyst & 272 & $137(50.4)^{\mathrm{b}}$ \\
Expanding blastocyst & 72 & $11(15.3)^{\mathrm{c}}$ \\
\hline
\end{tabular}

values within rows with different superscripts differ as follow:

$\mathrm{a}, \mathrm{b}-\mathrm{P}<0.01 ; \mathrm{b}, \mathrm{c}-\mathrm{P}<0.001$

${ }^{14}$ Sigma Chemical Co., St. Louis, MO, USA 
TABLE 2

The influence of perforation technique on the hatching of late blastocysts

\begin{tabular}{lcc}
\hline Stage of embryo & $\begin{array}{c}\text { Embryos } \\
\mathrm{n}\end{array}$ & $\begin{array}{c}\text { Hatching of blastocysts according to figure } \\
\text { eight pattern, \% }\end{array}$ \\
\hline Puncturing & 272 & $137(50.4)^{\mathrm{a}}$ \\
Slitting & 190 & $93(48.9)^{\mathrm{h}}$ \\
\hline
\end{tabular}

$\mathrm{a}, \mathrm{b}-\mathrm{P}<0.01$

re-expansion ability. Sixteen $(94.1 \%), 133(97.0 \%)$ and $10(90.9 \%)$ half pairs expanded in the middle, late and expanding blastocyst stages, respectively (data not included in the table).

Of the 190 late blastocysts with slit zona pellucida which were used, eight-inshape hatching was seen in 93 embryos $(48.8 \%$ ) (Table 2 ). Of the halves obtained after splitting hatching blastocysts and cultured in vitro, 91 pairs of halves were capable of re-expansion (97.8\%). From 7 blastocysts hatching in the eight-inshape way 14 halves were obtained and their quality determined on the basis of cell numbers. In individual blastocyst pairs the following numbers of cells were seen: $39 / 58 ; 53 / 61 ; 44 / 45 ; 49 / 38 ; 37 / 45 ; 42 / 48 ; 50 / 41$. Demi-embryos obtained after splitting 35 hatching eight-in-shape blastocysts were transferred into 41 recipients ( 12 heifers received single halves). Seventeen recipients became pregnant. All animals calved, giving 20 calves including 4 pairs of monogenetic twins (Table 3).

TABLE 3

Results of transfer of bovine demi-cmbryos derived from zona perforated hatching blastocysts after modified bisection

\begin{tabular}{ccccc}
\hline $\begin{array}{l}\text { No. of } \\
\text { blastocysts }\end{array}$ & Kind of bisection & $\begin{array}{c}\text { No. of } \\
\text { recipients/No. of } \\
\text { transferred halves }\end{array}$ & $\begin{array}{c}\text { No. of pregnant } \\
\text { recipients }\end{array}$ & $\begin{array}{c}\text { No. of calving/ } \\
\text { No. of calves }\end{array}$ \\
\hline 35 & modified & $12 / 1$ & 4 & $4 / 4^{*}$ \\
13 & standard & $13 / 2$ & 13 & $13 / 16^{* *}$ \\
\hline
\end{tabular}

* - including 1 pair of monozygotic twin

**- including 3 pairs of monozygotic twins

In the control group 13 blastocysts were bisected. The resulting pairs were transferred in to 13 recipients. Two became pregnant giving 3 calves, including a set of identical twins.

Of 25 in vivo produced blastocysts perforated and then cultured in vitro, 18 $(72 \%)$ hatched as previously described. Seventeen of these half pairs $(94.4 \%)$ reexpanded in vitro (data not included in the tables). 
a)

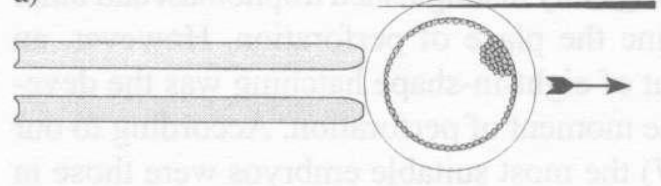

b)

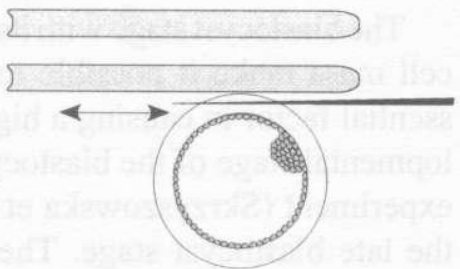

Figure 1. A diagrammatic representation of a zona pellucida perforation technique using a glass microneedle (partial zona dissection):

$\mathrm{a}$ - attachment of the blastocyst to the holding pipette (note position of the inner cell mass) and insertion of the glass needle under zona pellucida,

$\mathrm{b}$ - release of the embryo from the holding pipette (the embryo is "hung" on the glass needle) and placing it under the holding pipette. By scrapping the needle along the holding pipette the zona pellucida is slit

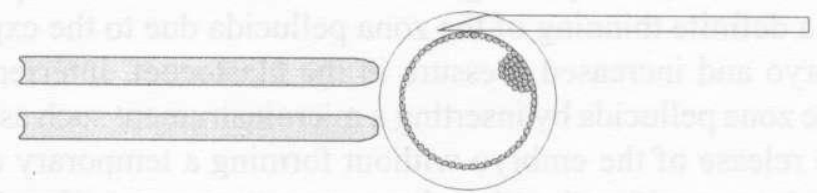

Figure 2. A diagrammatic representation of a zona pellucida perforation technique by puncturing with a micropipette

\section{DISCUSSION}

The developed method is a minimaly invasive technique of bovine embryo splitting during their eight-in-shape hatching due to previous zona pellucida perforation.

In our study, the zona pellucida of blastocysts was perforated above the trophoblast not far from the inner cell mass. Localization resulted in approximate equal proportions of the inner cell mass and trophoectodermal cells extruding from the zona pellucida.

Earlier, the perforation technique of the zona pellucida done on mouse and human embryos was used to improve the effectiveness of in vitro fertilization (Gordon et al., 1988; Malter and Cohen, 1989) as well as improving blastocyst hatching (Cohen and Feldberg, 1991; Khalifa et al., 1992). For this purpose, the embryos usually at zygote to morula stages were zona perforated. At these embryo stages the perforation had to be done at random. It was possible, that during hatching, the mass or simultanously both cell types could extrude through a hole in the zona pellucida. In this case the manner of hatching was not essential. However transfer of zona-perforated embryos into recipients can enhance the incidence of monozygotic twins even in the absence of any further attempt to split the embryo (spontaneous monogenetic twins as a result of specific hatching). 
The blastocyst stage with its morphologically distinguished trophoblast and inner cell mass make it possible to determine the place of perforation. However, an ssential factor in causing a high percent of eight-in-shape hatching was the developmental stage of the blastocysts at the moment of perforation. According to our experiment (Skrzyszowska et al., 1997) the most suitable embryos were those in the late blastocyst stage. The proportion of zona perforated late blastocyst hatching in the eight-in-shape way was decidedly higher than embryos perforated at middle or expanded blastocyst stage. Perhaps this was a consequence of changes in the zona thickness during embryo development. At the mid-blastocyst stage, the zona pellucida was relatively thick and for hatching embryos it was a significant barrier, especially if the puncture in the zona was very small. Possibly enlarging the opening by cruciate thinning (Khalifa et al., 1992) would improve specific embryo hatching at an earlier blastocyst stage. However in the case of expanding blastocysts there is a definite thinning of the zona pellucida due to the expansion of the growing embryo and increased pressure in the blastocoel. Interference with the integrity of the zona pellucida by inserting a microinstrument such as a glass needle can cause the release of the embryo without forming a temporary eight-in-shape figure. Taking into consideration that about seventy per cent of perforated blastocysts hatch in culture in vitro but for the in-eight-shape way this percentage is distincly lower (Table 1) particularly the case of expanded blastocyst can testify a role of zona pellucida tickness in this procedure.

The splitting of eight-in-shape hatching blastocysts involve minimal cell losses within only the narrow cell bridge connecting the two parts of the hatching embryo. In our experiment we did not determine the rate of destroyed cells but only the size of both embryo parts (on the basis of cell numbers) at the moment of bisection. The parts of embryos differed as to cell number but this difference was not significant.

The decisive criterion evaluation of demi-embryos obtained by using the embryo splitting of eight-in-shape hatching blastocysts were biological tests. This experiment was carried out under farm conditions on embryos produced in vivo i.e. from superovulated donor heifers. These tests resulted in monozygotic twins and several single births. They were the first pairs of monozygotic calves obtained by transferring halves derived from modified splitting. In comparison to results obtained after conventional bisection these were better. Unfortunately the results of standard bisection in this experiment were very low in comparison to the results of other authors (Mc Evoy and Sreenan, 1990; Kippax et al., 1991). They therefore cannot be a good reference for the modified method of bisection. The results to date indicate that this method may be considered as an alternative to standard bisection. As to whether this method will be used in practice depends on its effectiveness on a wider scale. 


\section{REFERENCES}

Baker R.D., 1985. Commercial splitting of bovine embryos. Theriogenology 23, 3-12

Bredbacka P., Huhtinen M., Aalto J., Rainio V., 1992. Viability of bovine demi- and quarter-embryos after transfer. Theriogenology 38, 107-113

Cohen J., Feldberg D., 1991. Effects of the size and number of zona pellucida openings on hatching and trophoblast outgrowth in the mouse embryo. Mol. Reprod. Develop. 30, $70-78$

Gordon J.W., Grunfeld L., Garrisi G.J., Talansky B.E., Richards Ch., Laufer N., 1988. Fertilization of human oocytes by sperm from infertile males after zona pellucida drilling. Fertil. Steril. 50, 68-73

Kątska L., Ryńska B., 1993. Developmental capacity of bovine zygotes co-cultured with fresh and frozen oviduct epithelial cells. Anim. Sci. Papers Rep. 11, 121-126

Khalifa E.A.M., Tucker M.J., Hunt P., 1992. Cruciate thinning of the zona pellucida for more successful enhancement of blastocyst hatching in the mouse. Human Reprod. 7, 532-536

Khalifa E.A.M., Tucker M.J., Hunt P.P., Hamicki J., 1993. Improved hatching in mouse embryos brought about by combined partial zona dissection and co-culture. Human Reprod. 8, 599-603

Malter H.E., Cohen J., 1989. Partical zona dissection of the human oocyte: a non-traumatic method using micromanipulation to assist zona pellucida penctration. Fertil. Steril. 51, 139-143

Menezo Y., 1976. Mise au moint d'un artificiel defini pour la survie et la maturation des gametes et pour la culture de l'oeuf fécondé. CR Acad. Sci. Paris 1967-1970

Ozil J.P., 1983. Production of identical twins by bisection of blastocysts in the cow. J. Reprod. Fert. $69,463-468$

Skrzyszowska M., Smorag Z., 1989. Cell loss in bisected mouse, sheep and cow embryos. Theriogenology $32,115-122$

Skrzyszowska M., Smorag Z., Kątska L., 1997. Demi-embryo production from hatching of zonadrilled bovine and rabbit blastocyst. Theriogenology $48,551-557$

\section{STRESZCZENIE}

\section{Monogenetyczne bliźnięta u bydla po transplantacji połówek zarodków uzyskanych metodą zmodyfikowanej bisekcji}

Badania miały na celu określenie możliwości rozwojowych połówek zarodków bydlęcych uzyskanych w wyniku zmodyfikowancj bisckcji. Zarodki w stadium późnej blastocysty poddawano mikrochirurgicznemu zabiegowi nakłuwania lub nacinania osłonki przejrzystej w okolicy węzła zarodkowego. W trakcie hodowli in vitro u pewnego odsetka perforowanych zarodków obserwowano specyficzny sposób wylęgania, polegający na ekspansji komórek zarodka przez otwór w osłonce przejrzystej. Wylęgający się wg tego schematu zarodek na pewnym etapie przypomina kształtem postać ósemki. Przecięcie mostka komórkowego łączącego obie części zarodka pozwalało na uzyskanie dwóch ekwiwalentnych ,połówek”, które przenoszono następnie do dróg rodnych zsynchronizowanych biorczyń.

Z 35 wylęgających się wg tego wzorca blastocyst, 12 połówek (7. 6 zarodków) przeniesiono pojedynczo do 12 biorczyń uzyskując po wycieleniu 4 biorczyń $(33,3 \%) 4$ cielęta, w tym parę monogenetycznych bliźniąt. Dwudziestu dziewięciu biorczyniom transplantowano natomiast po dwie polówki, uzyskując po wycieleniu 13 biorczyń 16 cieląt $(27,6 \%)$.

Biorąc pod uwagę wyniki próby biologicznej można stwierdzić, żc zmodyfikowana metoda dzielenia zarodków w trakcie ich prowokowanego wylęgania pozwala na uzyskanie monogenetycznych bliźniąt u bydła, a tym samym może być rozważana jako alternatywna metoda dzielenia zarodków. 